tion as colleges or universities that had libraries were included.

The Survey of College and University Libraries achieved a response rate of $91 \%$. The data for a non-responding institution were imputed by using data of a peer institution of similar characteristics, based on control and level, enrollment size, NCES classification, level of offering, and state of the geographic location.

\title{
Mentoring in the academic library
}

\author{
Deanna L. Roberts \\ Social Sciences Bibliographer \\ University of Georgia
}

\section{Professional development through observation and consultation.}

\begin{abstract}
$\mathrm{M}$ entoring to accelerate an individual's professional development is not a novel concept in either business or academia. This master-apprentice or teacher-student relationship occurs informally in many organizations, and formalized mentoring programs have been successful both in the federal government as well as the private sector. Linda Phillips-Jones, in her article on establishing mentoring programs, states that “.... among the most successful in the federal government include those in the Internal Revenue Service, the Federal Executive Development Program, and the Presidential Management Intern Program. In the private sector, programs have been established in such corporations as Jewel Companies, American Telephone and Telegraph's Bell Laboratories, and Merrill Lynch." In academic libraries, the Council on Library Resources Internship Program was implemented in 1974 to provide a first-hand leadership perspective to experienced professionals in order to enhance their knowledge and understanding of the

${ }^{1}$ Linda Phillips-Jones, "Establishing a Formalized Mentoring Program," Training and Development Journal 37 (Febraury 1983):38.
\end{abstract}

complexities of research libraries. It is time to take a new look at the idea of mentoring programs in the academic library as a means of staff development for the junior professional or recent library school graduate.

While the definitions of a mentor are many and varied-coach, model, guide, teacher, sponsor, or advisor - the purpose is the same. This relationship allows new people to observe departmental activities, divisional functions and goals, in addition to the policies and procedures of the organization, through consultation with the experienced professional. Elizabeth Bolton, a specialist in public affairs education, advises that "the most important element in this type of relationship is the willingness to share accumulated knowledge with another individual in the novice stage of development whether on the same occupational level or from a higher position."2

${ }^{2}$ Elizabeth B. Bolton, "A Conceptual Analysis of the Mentor Relationship in the Career Development of Women," Adult Education 30 (Summer 1980):205. 


\section{Benefits to the protege}

At the University of Georgia Libraries an experimental mentoring program was tested during a three month period in 1985 . In my present position as a social sciences bibliographer, I participated in a mentoring-protege relationship with the assistant director of branch libraries. During this program I

\section{Mentoring can be a faster means of learning than direct experience.}

attended weekly staff meetings with library faculty responsible for collection development and public service in the sciences, maps, reference, and medical resources.

The benefits derived from this opportunity to learn by association were many. Sharing in group meetings and other individual conferences between the assistant director and her staff provided me with a clearer understanding of the functions and activities of this division in relation to the complete library system as well as the academic community. I also had the opportunity to discuss my concerns relating to personnel supervision, collection development activities, and organizational goals. Kathy Kram, author and researcher in the field of organizational behavior and adult relationships in organizations, has suggested that "when one attempts to develop technical, socialmanagerial skills in a professional role, the opportunity to watch and consult with someone who is successful is invaluable." 3 This type of modeling early in a career may be an important contribution to the formation of a professional identity. It may also provide a faster means of learning than direct experience can. The new librarian is allowed to address concerns about skills, performance, or competence and derives reassurance in knowing that one may express uncertainty about issues with a more experienced professional without risking disclosure to the total organization. In my own situation, the fact that I had the opportunity to discuss matters of importance to me with someone I respected and trusted had a positive effect on the way I perceived my career potential, and my relationship to the organization.

Michael Zey, in his book The Mentor Connection, proposes "the fact that someone in the organization cares about the protege's success and organizational performance gives the protege a feeling of

${ }^{3}$ Kathy E. Kram, Mentoring at Work: Developmental Relationships in Organizational Life (Glenview, Ill.: Scott, Foresman, 1985), p.113. self-worth that transcends title and salary and figures heavily in the amount of satisfaction one gets from performing his job." ${ }^{4}$ By witnessing discussion and being included in decision-making, a new professional may become more confident in the organization and those people in authority. This process may produce more active library faculty members during a period of initiation and exploration in an organization.

\section{Benefits to the mentor}

The protege is not the only one who gains from this type of work relationship. By sharing knowledge and skills the advisor may gain personal satisfaction and respect from colleagues. The experienced librarian may have questions concerning competence or relationships with either peers or new professionals. The teaching process may require the mentor to review and reappraise day-today actions and assumptions. The experienced person may be challenged to think more clearly and creatively. The program may also provide otherwise nonexistent opportunities for interaction between librarians at similar or different career stages. Development of staff through teaching, observation, and discussion can provide the experienced librarian with an opportunity to give expertise back to the organization.

The supervisor who is in a position to develop talent is reminded to acknowledge the developing skills of a new professional. This advisor is able to make assessments without the problem of partiality or prejudice that a direct supervisor faces. An additional benefit of this relationship is that it allows the mentor to evaluate ideas with another professional before acting on a decision.

By formalizing the relationship, the organization acknowledges the skills and experience of the advisor. This is the type of reinforcement the more experienced professional may be seeking.

\section{Benefits to the organization}

Academic librarians have realized all too well that there are some things that cannot be learned from text books or formal class lectures. In her address to an ARL meeting, Patricia Battin admitted that "educational programs for academic librarianship have continued to stress an individualistic bias-the concept of the autonomous professional - and have actively promoted and encouraged the development of narrow specialists, either in academic subject disciplines or within the library profession."5

${ }^{4}$ Michael Zey, The Mentor Connection (Homewood, Ill.: Dow Jones-Irwin, 1984), p.72.

${ }^{5}$ Patricia Battin, "The Real World: Large Library Organizations," Minutes of the 101st Meeting, Arlington, Virginia, October 13-14, 1982 (Washington, D.C.: Association of Research Libraries, 1982), p.134. 
Mentoring can help build the needed networks between these "autonomous" professionals. The benefits are worth consideration. Professional development is a primary concern of library administration. Not all academic libraries have the number of personnel or the financial resources to provide lengthy internships or job sharing, but many of these same libraries have talented established professionals who could provide the beginning librarian with a more complete working knowledge of the organization and propose how they fit into that complex structure.

The ability to work and deal with a wide variety of people is essential in the research library. An organizational environment that promotes communication between its staff is, in effect, providing individuals with an opportunity for integration and socialization. The professional who better understands the goals and mission of the library with the support and interest of experienced colleagues in turn may become a more committed individual. Enhancing the skills of new librarians may lead to their reduced insecurity and increased productivity. Mentoring may also provide the organization with a means of rewarding (e.g., performance appraisal) the mentor for developing and collaborating with junior members of the professional staff.

\section{Important criteria for the mentoring program}

Considering mentoring relationships as a means for professional development requires acknowledgement that it should be strictly voluntary. Not all established librarians feel that they are capable teachers or advisors, nor are all beginning librarians looking for one. These relationships should be viewed as experimental, allowing the mismatched or disillusioned participants to shift or withdraw from the commitment.

Keeping the length of the program to a reasonable duration with clearly stated expectations from the volunteers keeps the program from becoming a burden. In some instances the participants may decide to continue their relationship on a less formal basis.

In addition, the organization should publicize its support of the mechanics and goals of the mentoring program through meetings, discussions, and written communication. It is essential that supervisors and others who may be affected by the relationship be allowed to express their concerns and ideas.

Final aspects of this program include monitoring and evaluation. This may be accomplished through reports, meetings, or the completion of actual projects.

\section{Conclusion}

Unfortunately, some professionals still perceive learning as something that is accomplished in a special course or left to the individual to gain through trial and error; however, positive working relationships may contribute to both the individual's professional and personal growth and the organization's increased effectiveness. Collaboration and sharing of experience and knowledge with one's colleagues through advisor-student or mentorprotege relationships is a practical, in-house means of providing professional development for the junior professional or recent library school graduate in the academic library.

\section{CLR-funded Professional Development Program}

Nine librarians have been selected to participate in a new Professional Development Program funded by the Council on Library Resources and involving the libraries of the University of Chicago, the University of Illinois at Chicago, and Northwestern University. The Fellows selected for the 1985-86 program are Jane Ciacci, Yvonne Glanze, and Camille Riley from the University of Chicago; Stephen Bloom, Gunnar Knutson, and Terri Licari from the University of Illinois at Chicago; Mary Margaret Case, Lloyd Davidson, and Jean Dickson from Northwestern University.

These nine Fellows are the first group to be selected for the program, which the Council has funded for its first three years. Each academic year the group of Fellows participates in a series of seminars dealing with issues and problems facing research libraries. More experienced staff from the libraries of the cooperating universities and faculty from the Graduate Library School of the Univer- sity of Chicago plan and lead the seminars.

This year's series of seminars focuses on the basic functions of the library. Joint planning groups consisting of staff from the three libraries have organized and presented seminars on collection development and management and on special collections. They are currently planning seminars on physical access to collections and on processing collections. Spring programs include a seminar to be presented by the three directors of the participating libraries. By the end of the year the program will have involved a number of staff members with varying levels of experience from the same library.

Similar groups of six to nine librarians with five or fewer years of experience will be selected as Fellows at the three libraries in upcoming years. For more information on the program, contact Melissa Trevvett, Program Director, University of Chicago Graduate Library School, 1100 East 57th Street, Chicago, IL 60637; (312) 962-8699. 